International Journal of Economics, Business and Accounting Research (IJEBAR)

Peer Reviewed - International Journal

Vol-1, Issue-2, 2017 (IJEBAR)

ISSN: 2614-1280

http://www.jurnal.stie-aas/ijebar

\title{
Effect of Real Earning Management on Company Performance (Empirical Study on Go Public Companies Indexed on JII)
}

\author{
Suhesti Ningsih \\ The College of Economics AAS Surakarta \\ Email : hesti.hegi@gmail.com,
}

\begin{abstract}
The purpose of this study is to determine the effect of real earning management on corporate performance on companies indexed in JII period 2013-2015. The research method used is explanatory which is designed to analyze earnings management practice for 3 years. The populations in this study are companies listed on the BEI in the Jakarta Islamic Index (JII) in 2013-2015. The technique of determining the sample in this study is purposive sampling. The data source used in this study is the annual financial statements published by publicly listed indexed companies in JII and published during the year 2013 to 2015. The results of the research with F test shows that together proxies real earning management that is cash flow operational, production cost and discretionary expense affect the performance of the company proxies with ROA. From the result of $t$ test is known proxy production cost and discretionary expense have an effect on to company performance, while proxy Cash flow operational does not have an effect on to company performance.
\end{abstract}

Keywords: Real Earning Management; CFO; PROD; DISCR; ROA

\section{Introduction}

Financial statements are sources of information used to assess the financial position and financial performance of a company which consists of income statement, statement of changes in equity, statement of financial position (balance sheet) and statement of cash flows. This financial report is used by investors, shareholders, creditors, suppliers, employees, and other financial analysts to obtain important information about the company that is useful in the decision making process. Basically, financial statements are an important source of information used by investors in assessing company performance. In the process of preparing financial statements cannot be separated from the intervention of managers related to the achievement of the desired profit targets of the company. The management modifies reported profits to look in good conditions with the aim that investors or creditors can invest.

Profit engineering done by ordinary managers is called earnings management. Profit management is closely related to the level of earnings or achievement of a company so it is not surprising that managers often try to accentuate achievement through the level of profit or profit achieved. Earnings management is an action performed by the management by raising or lowering reported profits from the unit in charge which has no relation to the increase or 
International Journal of Economics, Business and Accounting Research (IJEBAR)

Peer Reviewed - International Journal

Vol-1, Issue-2, 2017 (IJEBAR)

ISSN: 2614-1280

http://www.jurnal.stie-aas/ijebar

decrease in profitability in the long term. Approach in earnings management, namely earnings management with real approach and accrual approach (Accrual Earning Management). Accrual Earning Management is the management of profit through the use of accounting methods. While Real earning management is a manipulation performed by management through the real activities of everyday companies during the accounting period.

In this study, the profit management approach used is earnings management through real corporate activities (Real earning management). The concept of Roychowdhury (2006) show that real earnings management is done through Cash Flow Operational, Production Cost and Discretionary Expense. While to measure company performance using profitability ratio that is ROA (Return On Asset).

Research on real profit management has been done by Yusnita et al. (2015) with the results of real earnings management through, operating cash flow and production costs and the cost of simultaneous discretion have a significant effect on company performance. Instead research conducted by Koyuimirsa (2011) showed that there is no influence of the three elements of real profit management on the performance of the company. The studies that have been conducted among others by Mayar (2009), Oktorina et al. (2009), Fitriyani et al (2014), Sa'diyah and Hermanto (2017).

Based on the description above it can be formulated as follows: 1) how Cash Flow Operational effect on company performance? 2) How does Production Cost affect company value? 3) How does discretionary Expense affect the value of the company?. The purposes of this study are: 1) the influence of Cash Flow Operational on company performance 2) the influence of Production Cost on company performance 3) the influence of discretionary expense effect on company performance.

\section{Literature Review}

\subsection{Agency Theory}

According to Jensen and Mecking (1976) agency relations is a contract between managers (agents), with investors (principal). Principal is the party that employs agents to perform tasks for the interests of principal, while the agent is the party that runs the interests of principal. The existence of separation of ownership by principal by controlling by agent in an organization tends to cause conflict of agency among principal and agent.

The Agency Theory explains that if the company is in poor performance, managers can act opportunistically by raising accounting profit to hide bad performance, otherwise when companies in good performance managers act opportunistically by lowering their accounting earnings to postpone good performance (Suyudi, 2009). With the financial statements reported by the agency as accountable for performance, the principal may assess, measure and monitor the extent to which the agent works to improve its welfare and as a basis for compensation to agents. 
International Journal of Economics, Business and Accounting Research (IJEBAR)

Peer Reviewed - International Journal

Vol-1, Issue-2, 2017 (IJEBAR)

ISSN: 2614-1280

http://www.jurnal.stie-aas/ijebar

\subsection{Earning Management}

Fischer and Rosenzweig (1995) define earnings management as the actions of a manager by presenting a report raising the current period's profit from the business unit it is responsible for, without incurring any increase (decrease) of the unit's economic profitability in the long run. Meanwhile, according to Sulistyanto (2008) earnings management is an effort of corporate managers to intervene information in the financial statements with the aim of fooling stakeholders who want to affect the performance and condition of the company.

Profit management occurs when managers use consideration in financial reporting and transaction preparation to alter financial statements, in order to manipulate the amount of earnings to some stakeholders about the firm's economic performance or to influence the outcome of the agreement depending on the accounting figures reported (Healy and Wahlen; 1999).

\subsection{Real Earning Management}

Real Earning Management is management actions that deviate from normal business practices conducted with the primary objective to achieve profit targets conducted in three ways: manipulation of cash flow operations, decrease of expense of $\mathrm{d}$ discretionary and excess production. (Roychowdhury, 2006; Cohen and Zarowin, 2010).

Graham et al. (2005) proved that managers prefer real earnings management rather than accrual earnings management, since real earnings management activities are difficult to distinguish from optimal business decisions and are harder to select, even though the costs used in those activities are economically significant for the company. Real activity such as discretionary cost reduction is preferred by managers rather than accrual manipulations as a way of managing earnings.

According to Roychowdhury (2006) in Subekti, Kee and Ahmad (2010) Real earnings management is measured using abnormal cash flow operations (Abn CFO) and abnormal production cost (Abn PROD) greater than other companies and abnormal discretionary expenses (Abn DISC) is smaller.

\subsection{Cash Flow Operations}

Operating cash flows contain details of the amount of cash receipts and disbursements from the operations of the company. In Roychowdhury (2006) it is explained that the method used for operating cash flow to abnormal targets is sales management. Sales management is related to the manager's effort to increase sales during this accounting period in order to increase profits that match the targets set. Actions taken to increase sales are through offering excessive discounts and offering soft credit credits. This is all done to increase sales volume as well as achieve shortterm profit targets that will give effect to the good performance displayed by managers.

Cash Flow Abnormal operation / Abnormal cash flow operations (Abn CFO) are earnings manipulations made by a company through a cash flow operation that will have a cash flow lower than its normal level. 
International Journal of Economics, Business and Accounting Research (IJEBAR)

Peer Reviewed - International Journal

Vol-1, Issue-2, 2017 (IJEBAR)

ISSN: 2614-1280

http://www.jurnal.stie-aas/ijebar

$\mathrm{CFO}_{t} / A_{t-1}=\alpha_{0}+\alpha_{1}\left(1 / \log . A_{t-1}\right)+\beta_{1}\left(S_{t} / A_{t-1}\right)+\beta_{2}\left(\Delta S_{t} / A_{t-1}\right)+\varepsilon_{t}$

The estimated residual value of $\mathrm{CFO}$ is an abnormal value of CFO.

\subsection{Production cost}

Production costs can also affect the profits generated by the company. Roychowdhury (2006) explains that the decline in the cost of goods per unit of goods produced massively has the impact of reporting high operating margins and operating cash flow is lower than the level of abnormal sales. This overproduction technique is needed to achieve the expected demand by the company. Production in large quantities resulting in fixed overheads divided by large unit amounts of goods will result in an average cost each unit with cost of sales decreased.

Real profit management is done through the manipulation of production costs, where the company will have higher production costs than its normal level is called abnormal production cost / abnormal production cost.

Production Cost Formula

PROt $/ A_{t-1}=\alpha_{0}+\alpha_{1}\left(1 / \log . A_{t-1}\right)+\beta_{1}\left(S_{t} / A_{t-1}\right)+\beta_{2}\left(\Delta S_{t} / A_{t-1}\right)+\beta_{3}\left(\Delta S_{t-1} / A_{t-1}\right)+\varepsilon_{t}$

The estimated residual value of the production cost is an abnormal value of production cost.

\subsection{Discretionary Costs}

Management can reduce discretionary costs such as research and development expenses, advertising and sales, general costs in indirect periods and incomes. This strategy can increase profits. The profit manipulation that performs costs and development, advertising costs, sales costs, administration, and general expenses is discretionary abnormal / Abnormal Discretionary. Discretionary cost formula

$\operatorname{DISC}_{t} / A_{t-1}=\alpha_{0}+\alpha_{1}\left(1 / \log . A_{t-1}\right)+\beta\left(\Delta S_{t-1} / A_{t-1}\right)+\varepsilon_{t}$

The estimated residual value of the discretionary cost is an abnormal value of discretionary cost. Desription:

$A_{t-1}=$ Total assets of the company at the end of year $t^{-1}$

$\mathrm{S}_{\mathrm{t}}=$ Sales of the company at the end of the year $\mathrm{t}$

$\Delta \mathrm{S}_{\mathrm{t}}=$ The changes of company sales in year $\mathrm{t}$ compared to sales at the end of the year $\mathrm{t}^{-1}$

$\Delta \mathrm{S}_{\mathrm{t}-1}=$ The changes iof company sales in year $\mathrm{t}-1$ compared with sales at the end of the year $\mathrm{t}-2$

$\alpha, \beta=$ The regression coefficient

$\varepsilon_{t}=$ Long error at the end of year $t$

\subsection{Company Performance}

Definition of financial performance itself is one of the factors that show the effectiveness and efficiency in an organization in achieving its goals, effectiveness if management has the ability to choose a goal that can or something appropriate tool to achieve the goals set. The financial statements are the source of information used to measure how far the performance of 
International Journal of Economics, Business and Accounting Research (IJEBAR)

Peer Reviewed - International Journal

Vol-1, Issue-2, 2017 (IJEBAR)

ISSN: 2614-1280

http://www.jurnal.stie-aas/ijebar

the company. To assess the performance of company's financial ratios such as debt equity ratio (DER), return on equity (ROE), return on assets (ROA), net profit margin (NPM) and so forth. In this study the ratio used to measure company performance is asset (ROA). ROA is one of the profitability ratios that measure the ability of companies to earn profits in relation to total assets This ratio is used to see the ability of companies to manage each asset value they have to generate net profit after tax. The higher the ROA of a company, the better the company's ability to manage its assets. The ratio of ROA in this study is measured by the ratio between net income after tax to total assets of the company (Martono, 2004: 84). The formulas looking for ROA are as follows:

$$
R O A=\frac{\text { Net Profit After Tax }}{\text { Total assets }} \times 100 \%
$$

\subsection{Hypothesis}

Based on the theoretical framework and background above it can be arranged hypothesis:

H1: Cash Flow Operational positively affects the company's performance on go public company indexed in JII.

H2: Production cost positively affects the company's performance on go public company indexed in JII.

H3: Discretionary expenses positively affect the company's performance on go public company indexed in JII.

H4: Cash Flow Operational, Production cost and Discretionary expenses jointly affect the performance of companies on go public company indexed in JII.

\section{Resarch Methodology}

\subsection{Types Of Research, Population And Sampling}

This research is an exploratory research designed to analyze earnings management practice for 3 years. The populations in this study are companies listed on the BEI in the Jakarta Islamic Index (JII) in 2013-2015. The technique of determining the sample in this study is purposive sampling with the criteria used to select the sample are as follow:

a. go public companies or listed on the Indonesia Stock Exchange into the category of Jakarta Islamic Index (JII) during the period of December 31, 2012-2014 in a row.

b. The Company publishes its annual financial statements for the period of December 31, 2013-2015 which are stated in rupiah (Rp).

c. related research data is available.

\subsection{Data Collecting Method}

Sources of data used in this study are annual financial reports published by publicly listed companies that are indexed in JII and published during 2013 to 2015. Data collection methods is 
International Journal of Economics, Business and Accounting Research (IJEBAR)

Peer Reviewed - International Journal

Vol-1, Issue-2, 2017 (IJEBAR)

ISSN: 2614-1280

http://www.jurnal.stie-aas/ijebar

a documentary method where the data used is secondary data in the form of corporate financial statements through the page www .idx.go.id.

\subsection{Data Analysis Technique}

\subsubsection{Classical Assumtion Test}

a. Normality

The normality test is performed to determine whether data from real earnings management (all residual amounts of CFO + Cost of Discretion + Production Cost) have a normal distribution. Normality test has been done using Kolmogorov Smirnov.

b. Multicollinearity

Multicollinearity test is a test to see whether or not there is a correlation between independent variables in a regression model.

c. Heterocompatibility

Heterocompatibility test is a test performed to determine whether there are inequality of variance from residual one to other observations.

d. Autocorrelation

To see if there is a correlation between period $\mathrm{t}$ and the previous period $(\mathrm{t}-1)$.

\subsubsection{Model Feasibility Test}

a. Determination Test

This test is conducted to find out how much influence the independent variable to the dependent variable.

b. T Test

This $t$ test is used to test the effect of each independent variable Cash Flow Operational, Production cost and Discretionary expenses to the dependent variable Company Performance (ROA).

c. F Test

Statistical test $\mathrm{F}$ aims to examine the effect of all independent variables namely Cash Flow Operational, Production cost and Discretionary expenses to the dependent variable Company Performance (ROA).

d. Multiple regression

Multiple regression analysis is used to know the effect of free variable Cash Flow Operational, Production cost and Discretionary expenses to the dependent variable of Company Performance (ROA) either together or partially. In this research the multiple regression equation is:

$Y=a+b 1 X 1+b 2 X 2+b 3 X 3+e$ (Anto Dayan, 2000) 
International Journal of Economics, Business and Accounting Research (IJEBAR)

Peer Reviewed - International Journal

Vol-1, Issue-2, 2017 (IJEBAR)

ISSN: 2614-1280

http://www.jurnal.stie-aas/ijebar

\section{Results And Discussion}

\subsection{Classical Assumption Test}

The results of classical assumption test that has been done using SPSS 17 program as follows:

a. Normality test

Table 1

Normality Test

\begin{tabular}{llr}
\hline & & $\begin{array}{r}\text { Unstandardize } \\
\text { d Residual }\end{array}$ \\
\hline $\mathrm{N}$ & Mean & .0000000 \\
Normal Parameters & Stb & 7.74688680 \\
& Absolute & .101 \\
Most Extreme & Positive & .101 \\
Differences & Negative & -.073 \\
& & .101 \\
Test Statistic & & $.076^{c}$ \\
Asymp. Sig. (2-tailed) & & \\
\hline
\end{tabular}

From the results of tests conducted by Kolmogorov-Smirnov Test the results show normal because of the value of Asymp. Sig .076> .005.

b. Multicollinearity Test

\section{Table 2}

Multicollinearity Test

\begin{tabular}{cr}
\hline \multicolumn{2}{c}{ Collinearity Statistics } \\
\hline Tolerance & \multicolumn{1}{c}{ VIF } \\
\hline .920 & 1.087 \\
.957 & 1.045 \\
.956 & 1.046
\end{tabular}

The result of tolerance calculation value shows that there is no independent variable that has tolerance value less than 0.10 which means there is no correlation between independent variable and also from VIF value calculation result is more than 10 which means there is no 
International Journal of Economics, Business and Accounting Research (IJEBAR)

Peer Reviewed - International Journal

\section{Vol-1, Issue-2, 2017 (IJEBAR)}

ISSN: 2614-1280

http://www.jurnal.stie-aas/ijebar

correlation between variables, so it can be concluded that there is no multicollinearity between independent variables in the regression model.

c. Heteroscedasticity Test

The result of test that has been done by using Park Test result that the parameter coefficient for independent variable is not significant, hence can be concluded that regression model there is no heteroskedasticity (table 3).

Table

Heterocompatibility Test

\begin{tabular}{|c|c|c|c|c|c|c|}
\hline \multirow{2}{*}{\multicolumn{2}{|c|}{ Model }} & \multicolumn{2}{|c|}{$\begin{array}{l}\text { Unstandardized } \\
\text { Coefficients }\end{array}$} & \multirow{2}{*}{$\begin{array}{c}\text { Standardized } \\
\text { Coefficients } \\
\text { Beta }\end{array}$} & \multirow[b]{2}{*}{$\mathrm{t}$} & \multirow[b]{2}{*}{ Sig. } \\
\hline & & B & Std. Error & & & \\
\hline \multirow[t]{4}{*}{1} & (Constant) & 64.968 & 12.713 & & 5.110 & .000 \\
\hline & Abn. CFO & 66.136 & 69.386 & .121 & .953 & .344 \\
\hline & Abn. PROD & -18.716 & 42.316 & -.055 & -.442 & .660 \\
\hline & Abn. DISC & -107.305 & 80.877 & -.165 & -1.327 & .189 \\
\hline
\end{tabular}

a. Dependent Variable: Ln_U2i

d. Autocorrelation Tests

The results show that the tests that have been performed with the LM Test have resulted that the parameter coefficients for residual lags provide an unqualified probability of 0.202 , this indicates an indication of the absence of autocorrelation (Table 4).

Table 4

Test autocorrelation

\begin{tabular}{|c|c|c|c|c|c|c|}
\hline \multirow{2}{*}{\multicolumn{2}{|c|}{ Model }} & \multicolumn{2}{|c|}{$\begin{array}{l}\text { Unstandardized } \\
\text { Coefficients }\end{array}$} & \multirow{2}{*}{$\begin{array}{c}\text { Standardized } \\
\text { Coefficients } \\
\text { Beta }\end{array}$} & \multirow[b]{2}{*}{$\mathrm{t}$} & \multirow[b]{2}{*}{ Sig. } \\
\hline & & B & Std. Error & & & \\
\hline \multirow[t]{4}{*}{1} & (Constant) & .054 & .997 & & .054 & .957 \\
\hline & Abn. CFO & .920 & 5.427 & .022 & .169 & .86 \\
\hline & Abn. PROD & -.573 & 3.321 & -.022 & -.172 & .864 \\
\hline & Abn. DISC & -1.148 & 6.310 & -.023 & -.182 & .856 \\
\hline
\end{tabular}


International Journal of Economics, Business and Accounting Research (IJEBAR)

Peer Reviewed - International Journal

Vol-1, Issue-2, 2017 (IJEBAR)

ISSN: 2614-1280

http://www.jurnal.stie-aas/ijebar

$\begin{array}{lllllll}\text { Lg_Res1 } & -.168 & .130 & & -.163 & -1.290 & .202\end{array}$

a. Dependent Variable: Unstandardized Residual

4.2 Model Feasibility Test

Table 5

Model Feasibility Test

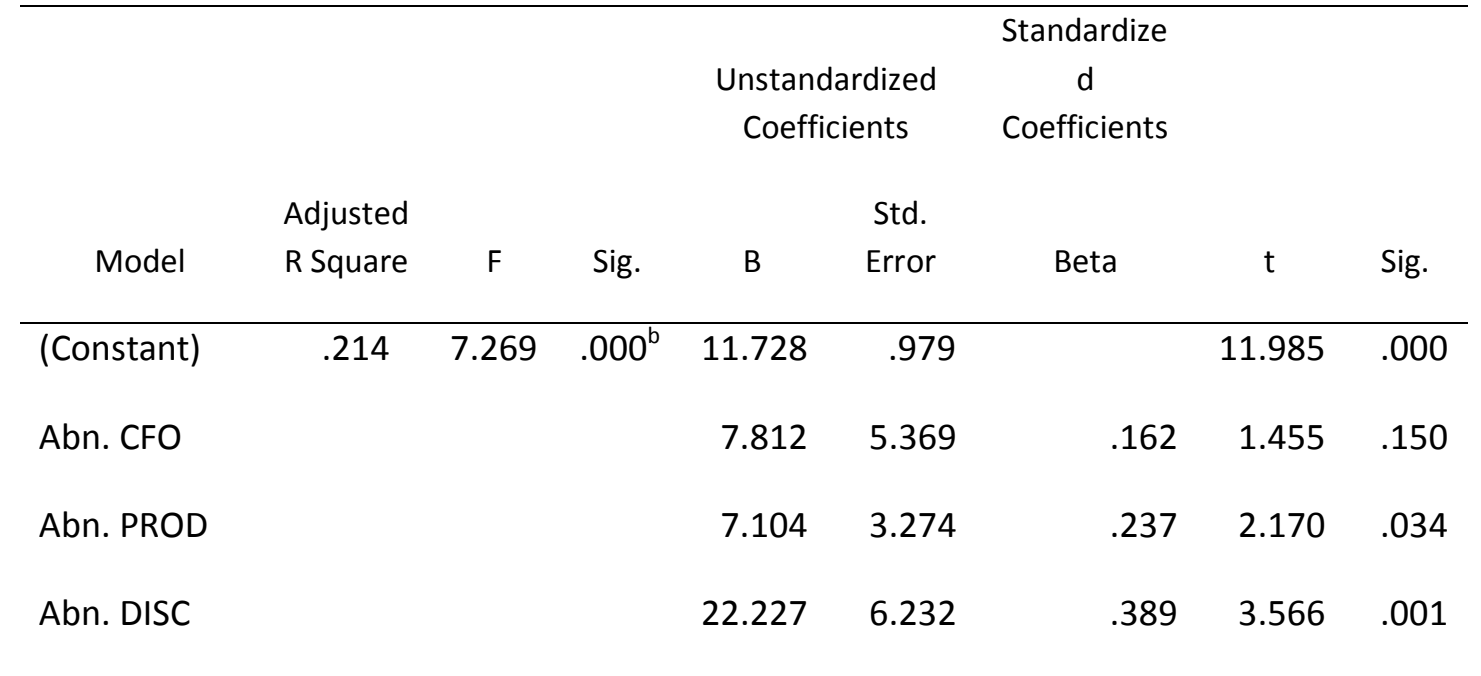

Source: Data processed with SPSS 17

From the results of feasibility test model (test) obtained a significance value of 0.000 smaller than 0.05 means a significant influence then the test model is feasible to use.

a. Determinant Test

From the statistical test result using spss (table 5) shows that the value of Adjusted R Square is equal to .214 or $21.4 \%$ which means that variability of dependent variable which can be explained by variability of independent variable equal to $21.4 \%$.

b. Individual Parameter Significant Test (t test)

This t test is used to test the effect of each independent variable of Operational Cash Flow, Production cost and Discretionary expenses to ROA dependent variable. From the results of tests that have been done to produce that sig value of three independent variables that have significant influence is variable abn. Prod of 0.035 and abn variable. Disc 0.001 means both $<0.05$, while for abn variable. CFO has no effect on ROA dependent variables, it is due to the value generated by the significance of $0.150>0.05$.

c. F test

This test is used to determine the feasibility of the model of all independent variables. The results show that the value generated by the sig in this $\mathrm{F}$ test is 0.000 , which means that the value is < probability 0.05 . So it can be concluded that of all independent variables 
International Journal of Economics, Business and Accounting Research (IJEBAR)

Peer Reviewed - International Journal

Vol-1, Issue-2, 2017 (IJEBAR)

ISSN: 2614-1280

http://www.jurnal.stie-aas/ijebar

significant to the dependent variable or can be said that variable abn. CFO, PROD, and DISC simultaneously affect the ROA variable.

d. Linear Regression Test

Based on the calculation of multiple regression which used to determine the effect of ROA on the independent variable Cash Flow Operational, Production cost and Discretionary, using SPSS 17 program, obtained the results obtained regression equation is as follows:

$\mathrm{Y}=11.728+7.812($ Abn. CFO) +7.104 (Abn. PPROD) +22.227 (Abn. DISC)

From the regression equation above shows that regression coefficient which has the biggest influence is variable abn. DISC, which produces a value of 22.227 , then followed by abn. CFO of 7,812 and last is abn. PROD of 7,104.

\section{Discussion}

From the results of statistical tests that have been done show that the variable Cash Flow Operational proxied with Abn. CFO of $0.150>\alpha(0.05)$, this means Abn. CFO has no significant effect on ROA on public go public indexed in Jakarta Islamic Index (JII). This shows that real earnings management on Cash Flow Operational proxy does not affect company performance. This proves that in improving the performance of the company management is not motivated to perform profit management actions through real activity on operating cash flow post. Operating cash flow occurs in accordance with the company's operations without any engineering from management. For example there is no engineering effort to boost cash income in order to increase profit or cash expenditures with the aim of reducing corporate profits.

The results of this study support research conducted by Wijayanti et al (2014) with the results of the research analysis shows that the approach to real earnings management through post operating cash flow does not affect the company performance. In contrast to the research that has been done by Yusnita et al (2015), states that there is influence of real earnings management through operating cash flow to company performance.

Result of test to variable Abn. Prod has an effect of 0.034 means $<0.05$, this shows the result that the variable Production cost has a positive and significant effect on the ROA variable in the public company indexed in JII. This shows that in showing the performance of the management to manage the real activity is on post production costs. To get the desired profit then the manager will make the emphasis on production costs by producing goods in large quantities that will be able to reduce production costs. As a result of the emphasis on production costs will reduce the selling price and is expected to increase sales so that will be obtained higher profits.

This is in line with research conducted Yusnita et al (2015), states that there is influence of real earnings management on post production costs with excess production affect the performance of the company. Contrary to research conducted Koyuimirsa (2011) showed that there is no effect of real earnings management through post production costs on the performance of the company. 


\section{Vol-1, Issue-2, 2017 (IJEBAR)}

ISSN: 2614-1280

http://www.jurnal.stie-aas/ijebar

The result of the research on Discretionary Expense variables shows that Abn. Disc 0.001 $<0.05$, this indicates Discretionary Expense has a positive and significant effect on ROA. This means that the management of earnings through discretionary costs is done to show better the company's performance. Management wants to show good performance then carried out the management in achieving the expected profit by emphasizing the cost of advertising, research and development costs of the company. The emphasis of discretionary costs will reduce the business costs so that it will increase the company's profit.

The results of this study support the research conducted by Yusnita et al (2015), states that there is influence of real earnings management on post production costs with excessive production affect the company performance. Bertolsk back with the results of research that has been done Koyuimirsa (2011) showed that the management of real earnings through post costs discreione not affect the company performance.

From result of $F$ test with significance equal to 0.000 , means that value $<0.05$ then this means test model is feasible to use. And simultaneously, three independent variables have significant effect on ROA. The results show that managers perform real earnings management through, operating cash flow and production costs and discretionary costs in an effort to boost company performance. This is in line with the results of research conducted by Yusnita et al. (2015) with the results of real earnings management through, operating cash flow and production costs and the cost of simultaneous discretion have a significant effect on company performance. Instead research conducted by Koyuimirsa (2011) showed that there is no influence of the three elements of real profit management on the performance of the company.

\section{Closing}

\subsection{Conclusion}

Based on the results of analysis and data test and discussion, then this research produce some conclusions as follows:

1. Operational cash flow, production cost and discretionary expense, simultaneously affect the company's performance (ROA) in the indexed company in JII year 2013-2015.

2. Operational cash flow has negative and insignificant effect on company performance (ROA) This means that real earnings management with proxy cash flow operational / operating cash flow does not affect company performance in indexed company in JII year 2013-2015.

3. Production cost and discretionary expense have positive and significant influence to company performance (ROA). This indicates that real earning management at Post Production cost and discretionary expense have an effect on to company performance in indexed company in JII year 2013-2015.

4. From the result of $\mathrm{R}^{2}$ test of 0.214 indicates that the influence of operational cash flow, production cost and discretionary expense to company performance (ROA) is $21,4 \%$ the rest equal to $78,6 \%$ influenced by other variables outside variable used in the study. 
International Journal of Economics, Business and Accounting Research (IJEBAR)

Peer Reviewed - International Journal

Vol-1, Issue-2, 2017 (IJEBAR)

ISSN: 2614-1280

http://www.jurnal.stie-aas/ijebar

\subsection{Suggestion}

Based on the research results and discussion it can be drawn some suggestions as follows:

1. For further researcher can do research using earnings management model of accrual

2. The influence of the variables in this study is very small that only amounted to $21.4 \%$, thus for further research can add other variables outside the variable in this study.

3. To better represent suggested for further research can be done on other companies such as indexed in compass 100, LQ45 and companies with other categories. Thus, it can be seen comparison in reporting earnings at these companies.

\section{Bibliography}

Ahmad K., Subekti I., \& Wijayanti A. (2010). The Real And Accruals Earnings Management: satu perspektif dari teori prospek. Kumpulan makalah Simposium Nasional Akuntansi (SNA) XIII, Purrwokerto.

Afreiyanti., M (2009). Pengaruh Accruals Earnings Management Dan Real Earning Management Terhadap Kinerja PerusahaanDengan Struktur Kepemilikan sebagai Variabel Moderasi studi empiris di BEI. Tesis. Program Pasca Sarjana Universitas Gajah Mada.

Brigham, EF., \& Joel F. H. (2006). Dasar-Dasar Manajemen Keuangan. Edisi kesepuluh. Buku satu. Jakarta: Salemba Empat.

Fischer, M., \& Rosennveig, K. (1995). Attitudes of Shidents and Accounting Practitioners concerning the Ethical Acceptability of Eamings Management. Journal of Business Ethics, Vol. 14, No. 6.

Fitriyani, D. dkk. (2014). Pengaruh Manajemen laba terhadap kinerja perusahaan dengan kualitas ausit sebagai variabel pemoderasi. Jurnal Dinamika Akuntansi, Vol. 6, No. 2

Graham, J. R., Harvey, C. R., \& Rajgopal, S., (2005). "The Economics Implications of Corporate Financial Reporting", Journal of Accounting and Economics, 40.

Husnan, S. (2005). Dasar-Dasar Teori Portofolio dan Analisis Sekuritas. Edisi Keempat. Penerbit UUP AMP YKPN: Yogyakarta.

Jensen, J.M. \& Meckling, W.H. (1999). Theory of the firm: managerial behavior, Agency costs and ownership structure. Journal of Financial Economics. V. 3, No. 4, .

Oktorina, M, \& Yanthi H. (2009), Analisis Arus Kas Kegiatan Operasi dalam Manipulasi Aktivitas Riil dan Dampaknya Terhadap Kinerja Pasar, Jurnal Riset Akuntansi Indonesia. Vol. 12, No. 1.

Roychowdhury, S. (2006). Earnings Management through Real Activities Manipulation. Journal of Accounting and Economic, 42, 335-370. 
International Journal of Economics, Business and Accounting Research (IJEBAR)

Peer Reviewed - International Journal

Vol-1, Issue-2, 2017 (IJEBAR)

ISSN: 2614-1280

http://www.jurnal.stie-aas/ijebar

Sa'diyah, S., \& Hermanto, A. (2017). Pengaruh Manajemen Laba Akrual dan Manajemen Laba Riil terhadap Nilai Perusahaan. Jurnal Ilmu dan Riset Akuntans. Vol. 6, No. 9.

Santoso. (2007). SPSS Statistik Parametrik. Penerbit PT Elex Media Komputindo: Jakarta.

Scott, W. R. (2006), Financial Accounting Theory Second edition. Canada Prentice Hall.

Sulistyanto, S. (2008). Manajemen Laba Teori dan Model Empiris, Grasindo, Jakarta.

Yusnita, H. dkk. (2007). Pengaruh Kualitas Corporate Governance Terhadap Kinerja Perusahaan Publik : Studi Kasus Peringkat 10 Besar CGPI. JAAI. Vol, 11 No.1, Juni 2007: 1-19. 